\title{
APPLICATION OF ASCORBIC ACID 2-PHOSPHATE AS A NEW VOLTAMMETRIC SUBSTRATE FOR ALKALINE PHOSPHATASE DETERMINATION IN HUMAN SERUM
}

\author{
Wei Sun* and Kui Jiao \\ College of Chemistry and Molecular Engineering, Qingdao University of Science and \\ Technology, Qingdao 266042, P.R. China
}

(Received January 26, 2005; revised May 10, 2005)

\begin{abstract}
An electrochemical assay of the enzyme alkaline phosphatase (ALP) using ascorbic acid 2-phosphate (AAP) as a new voltammetric substrate has been described in this paper. In the alkaline buffer solution the ALP enzymatic hydrolysis product of AAP was ascorbic acid (AA), which was an electro-active substance and had a sensitive differential pulse voltammetric (DPV) oxidative response on glassy carbon electrode (GCE) at $+380 \mathrm{mV}$ (versus $\mathrm{Ag} / \mathrm{AgCl}$ ), so the activity of ALP could be monitored voltammetrically of the oxidative peak current of AA. The electrochemical behaviours of AA were carefully studied and the AA standard solution could be measured by DPV method in the linear range from 10.0 to $1000.0 \cdot \mathrm{mol} / \mathrm{L}$ with the detection limit of $8.0 \cdot \mathrm{mol} / \mathrm{L}$. The optimal conditions for ALP enzymatic reaction and the voltammetric detection were optimized. Under the optimal conditions the calibration curve for ALP assay exhibited a linear range from 0.4 to $2000.0 \mathrm{U} / \mathrm{L}$ with a detection limit of $0.3 \mathrm{U} / \mathrm{L}$. This proposed method was further applied to determine the ALP content in healthy human serum and the results were in good agreement with the traditional $p$-nitrophenyl phosphate spectrophotometric method. The kinetic constants of enzymatic reaction were also investigated with the apparent kinetic constant $\mathrm{K}_{\mathrm{m}}$ as $2.77 \mathrm{mmol} / \mathrm{L}$ and the maximum velocity $\mathrm{V}$ as $0.33 \mathrm{~mol} / \mathrm{min}$.
\end{abstract}

KEY WORDS: Ascorbic acid 2-phosphate, Alkaline phosphatase, Voltammetry, Ascorbic acid, Enzymatic assay

\section{INTRODUCTION}

Alkaline phosphatase (ALP, EC. 3.1.3.1) is an important enzyme in immunoassay and bioanalytical chemistry, which is present in cell membranes of most of the organs and tissues of human body. The determination of enzyme activity of ALP and its iso-enzymes is a daily diagnostic program in hospital for numerous diseases. The increased ALP concentrations in human serum are perhaps linked with the disease of bone, liver, thyroid function or hepatobiliary [1,2]. ALP is also the most widely used labels in enzyme immunoassay for its high activity, low cost and non-specificity. ALP can catalyze the hydrolysis of phosphomonoesters and deliver the inorganic phosphate with corresponding alcohols. The activity of enzyme can be determined by measuring the amount of alcohols released. Many methods for ALP activity determination using different substrates have been proposed such as absorption spectrophotometry [3], fluorimetry [4], chemiluminescence [5] or bioluminescence and electrochemistry $[6,7]$. In absorption spectrophotometry, chromogenic substrates such as $p$ nitrophenyl phosphate (PNPP) have been commonly used, which produces the colored product of $p$-nitrophenol and the absorbance at $405 \mathrm{~nm}$ is measured. Phenolphthalein monophosphate, thymolphthalein phosphate, etc. can also be used for spectrophotometric analysis. In fluorescence assay, umbelliferyl phosphate has generally been used. However, absorbance measurement lacks adequate sensitivity and fluorescence detection often suffers from endogenous interferences. They are all limited by the interferences from lipemia and hemolysis

*Corresponding author. E-mail: sunwei_1975@public.qd.sd.cn 
of commonly clinical samples. The wide dynamic range and low detection limit of electroanalytical methods offer an attractive alternation to spectrophotometric method. A number of electrochemical substrates for ALP-labelled electrochemical immunoassay have been reported, such as phenyl phosphate, $p$-aminophenyl phosphate and so on [8-12]. ALP can catalyze these substrates to produce phenol or $p$-aminophenol, which is electroactive and can be easily detected by amperometry. Some of these substrates had also been applied to determine the serum ALP activity by electrochemical detection with flow injection analysis or HPLC [13, 14]. Recently Kawk et al. [15] proposed a new electrochemical method for the determination of serum ALP with $p$-nitrophenyl phosphate (PNPP) as substrate and indium tin oxide (ITO) film working electrode, PNPP was hydrolyzed enzymatically and the product $p$-nitrophenol was detected by cyclic voltammetry or square wave voltammetry at an oxidation potential of $+1.1 \mathrm{~V}$ (vs. $\mathrm{Ag} / \mathrm{AgCl}$ ). According to this method, ALP can be detected in various media including fetal bovine serum, human serum and untreated human blood with the linear dynamic range of ALP as $5-180 \mathrm{U} / \mathrm{L}$.

Ascorbic acid 2-phosphate (AAP) is another new alternative substrate for ALP assay and it had been compared with the widely used $p$-aminophenyl phosphate with electrochemical method in enzyme immunoassay [16]. The procedure of enzymatic hydrolysis reaction is shown as follows:

$$
\text { Ascorbic acid 2-phosphate }+\mathrm{H}_{2} \mathrm{O} \stackrel{A L P}{\longrightarrow} \text { Ascorbic acid }+\mathrm{H}_{3} \mathrm{PO}_{4}
$$

Kokado et al. had applied ascorbic acid 2-phosphate as substrate for ALP-labelled electrochemical enzyme immunoassay for the determination of human chorionic gonadotropin (HCG). The ALP activity was determined by amperometrically detection of ALP-generated-AA at a glassy carbon electrode in a flow injection system at $+400 \mathrm{mV}$. The optimal enzymatic reaction time was selected as $1 \mathrm{~h}$ and the detection limit was $1.6 \mathrm{pmol} / \mathrm{L}$ with the linear range as 1.6-5000 $\mathrm{pmol} / \mathrm{L}[17]$.

In this paper, this new electrochemical substrate was applied to the determination of serum ALP activity. The hydrolysis product, ascorbic acid (AA) is electroactive and could be detected by differential pulse voltammetry (DPV) at $+380 \mathrm{mV}$, which could be used for the determination of ALP concentration. Under the selected conditions, the established method was further applied to the determination of ALP content in human serum and the results were compared with the traditional $p$-nitrophenyl phosphate (PNPP) spectrophotometric method. The analytical results showed that this new electrochemical method was practical and reliable. Compared with the Kokako's paper [17], this method has the advantages of simple procedure, short reaction time and cheap equipment. Although the detection limit is not very attractive, the linear range of 0.4 to $2000.0 \mathrm{U} / \mathrm{L}$ is wide enough for the clinical diagnoses of serum ALP content determination, which is in the range of $40-130 \mathrm{U} / \mathrm{L}$.

\section{EXPERIMENTAL}

\section{Apparatus}

A CHI model 832 (Shanghai CH Instrument, China) electrochemical analyzer was used throughout for the voltammetric detection with a three-electrode system composed of a glassy carbon electrode (GCE, $\Phi=3.08 \mathrm{~cm}$ ) as the working electrode, a $\mathrm{Ag} / \mathrm{AgCl}$ (saturated $\mathrm{KCl}$ ) reference electrode and a platinum wire counter electrode. Spectrophotometric measurements were carried out on a Varian Cary 50 probe UV-Vis spectrophometer (Varian, Australia). All the values of $\mathrm{pH}$ of the buffer solution were controlled by a pHs-25 acidity meter (Shanghai Leici Factory, China) and a GSY-II thermostatic water bath was used to control the reaction temperature (Beijing Medical Instrument Factory, China). 
Reagents

Alkaline phosphatase (EC 3.1.3.1. from calf intestine, $18 \mathrm{U} / \mathrm{mg}$, ALP) was obtained from Sigma and a $1.0 \times 10^{4} \mathrm{U} / \mathrm{L}$ ALP stock solution was prepared by dissolving $28.0 \mathrm{mg}$ ALP into $50.0 \mathrm{~mL}$ of $0.05 \mathrm{~mol} / \mathrm{L} \mathrm{pH} 7.4$ Tris-HCl buffer solution (containing $1.0 \mathrm{mg} / \mathrm{mL} \mathrm{MgCl}_{2}$ ) and stored at $4{ }^{\circ} \mathrm{C}$. Ascorbic acid 2-phosphate (AAP) was purchased from Sigma and $0.15 \mathrm{~mol} / \mathrm{L}$ AAP solution was prepared freshly before use to minimize the non-enzymatic hydrolysis. Ascorbic acid (AA) was obtained from Shandong Zibo Chemical Factory and $0.05 \mathrm{~mol} / \mathrm{L}$ Tris-HCl buffer solution was used to control the acidity of the reaction solution. The spectrophotometric substrate for ALP, $p$ nitrophenyl phosphate (PNPP) was obtained from Amersco (USA). ALP labeled goat anti-rabbit IgG (IgG-ALP) was obtained from Beijing Huamei Biotechnical Company. The healthy human serum samples were kindly provided by the Hospital of Qingdao University of Science and Technology, they were collected from healthy man's veins and centrifuged at $2500 \mathrm{rpm}$ to get sera. All the chemicals used were of analytical grade and doubly distilled water was used to prepare all aqueous solutions.

Procedures for ALP assay

Electrochemical studies of ascorbic acid. Cyclic voltammetry or differential pulse voltammetry were performed on the standard AA solution, which was prepared by diluting a stock solution of $2.0 \times 10^{-4} \mathrm{~mol} / \mathrm{L}$ AA with $0.05 \mathrm{~mol} / \mathrm{L}$ Tris- $\mathrm{HCl}$ buffer solution. Solutions were scanned in the potential range from 0 to $1.0 \mathrm{~V}(\mathrm{vs}$. $\mathrm{Ag} / \mathrm{AgCl}$ ) and the oxidative peak current of $\mathrm{AA}$ at $+0.39 \mathrm{~V}$ was recorded.

Voltammetric determination of ALP activity. In a $10 \mathrm{~mL}$ colorimetric tube, $0.5 \mathrm{~mL}$ of $0.15 \mathrm{~mol} / \mathrm{L}$ AAP and $3.5 \mathrm{~mL}$ of $0.05 \mathrm{~mol} / \mathrm{L} \mathrm{pH} 8.8$ Tris- $\mathrm{HCl}$ buffer solution was mixed together. Different amount of ALP standard solutions or human serum samples were then added, mixed homogenously and the solution was diluted to $5.0 \mathrm{~mL}$. After reaction at $37^{\circ} \mathrm{C}$ for $40 \mathrm{~min}$, the enzymatic reaction was stopped by the addition of $27.0 \mu \mathrm{L}$ of $4.0 \mathrm{~mol} / \mathrm{L} \mathrm{H}_{3} \mathrm{PO}_{4}$ and the solution was transferred to a $10 \mathrm{~mL}$ electrochemical cell. The differential pulse voltammogram (DPV) of the enzymatic product, AA, was recorded over the potential range from 0 to $650 \mathrm{mV}$ with a CHI 832 electrochemical analyzer. The DPV parameters were selected as: pulse width $0.06 \mathrm{~s}$, pulse period $0.2 \mathrm{~s}$, potential increment $0.015 \mathrm{~V}$.

Spectrophotometric determination of ALP activity. The spectrophotometric assay of ALP activity was performed with $p$-nitrophenyl phosphate (PNPP) as substrate [3]. The ALP solution or human serum samples were mixed with $15 \mathrm{mmol} / \mathrm{L}$ PNPP, which was buffered in $\mathrm{pH} 10.3$ diethanolamine (DEA) solution and the absorbance of enzymatic product, $p$-nitrophenol, was detected at $405 \mathrm{~nm}$ by Cary 50 probe spectrophotometer.

\section{RESULTS AND DISCUSSION}

\section{Electrochemical studies of ascorbic acid}

The electrochemical behavior of AA was examined by cyclic voltammetry (CV) on the glassy carbon electrode (GCE) in quiescent bulk solution. A single and irreversible oxidative peak was obtained with the peak potential value at $+400 \mathrm{mV}$ (vs. $\mathrm{Ag} / \mathrm{AgCl}$ ). By performing $\mathrm{CV}$ experiments at various scan rate over the same potential range a linear relationship was obtained between the anodic current of AA and the scan rate in the range of $1.0 \sim 350.0 \mathrm{mV} / \mathrm{s}$ with the 
linear regression equation as Ip $(\mathrm{nA})=274.1+2.67 v(\mathrm{mV} / \mathrm{s})(\mathrm{n}=15, \gamma=0.998)$. The results indicated that the oxidative reaction on GCE was controlled by adsorption process. The oxidation peak potential shifted negatively with the increase of $\mathrm{pH}$ of buffer solution in the $\mathrm{pH}$ range of $6.0 \sim 10.5$ and a plot of Ep versus $\mathrm{pH}$ was constructed with the linear regression equation as Ep $(\mathrm{V})=-0.060 \mathrm{pH}+0.93$, which indicated that $\mathrm{H}^{+}$participating in the oxidative reaction. The multiple sweep cyclic voltammogram of AA solution showed that the oxidative peak current decreased with the repetitive scans, which indicated that the oxidative product of AA can be adsorbed on the surface of electrode and caused the fouling of the electrode surface as the results of electro-polymerization of phenolic radicals and decrease of the active area of electrode surface. In order to get the reproducibility of the analytical result, the GCE was polished with $0.05 \mu \mathrm{m}$ alumina powder and allowed to achieve a low current baseline in the buffer after each detection.

Optimal conditions for voltammetric detection of AA and its stability

Because AA is the product of the ALP enzymatic hydrolysis reaction of AAP, so the optimal conditions for the detection of AA was investigated by differential pulse voltammetry (DPV) on GCE. The influence of the $\mathrm{pH}$ of the buffer solution on the determination of AA was studied in the $\mathrm{pH}$ range from 2.4 to 10.0 and the result was shown in Figure 1. It can be seen that in $\mathrm{pH}$ 4.9 Tris-HCl buffer solution the response of the oxidative peak current showed the greatest sensitivity and reached maximal. So $\mathrm{pH} 4.9$ of buffer solution was selected as the best detection medium for AA. Since the ALP has the maximal enzyme activity at alkaline solution, so higher concentration of $\mathrm{H}_{3} \mathrm{PO}_{4}(4.0 \mathrm{~mol} / \mathrm{L})$ was used to stop the enzymatic reaction and adjusted the reaction medium to the suitable conditions for AA detection. Under the optimal conditions, the linear range of AA detection by DPV was obtained from 10.0 to $1000.0 \mu \mathrm{mol} / \mathrm{L}$ with the detection limit of $8.0 \mu \mathrm{mol} / \mathrm{L}$ and the linear regression equation of the calibration curve was $\operatorname{Ip}(\mathrm{nA})=0.595+0.0492 \mathrm{C}(\mu \mathrm{mol} / \mathrm{L})(\mathrm{n}=12, \gamma=0.998)$. The RSD for eleven parallel determination of $30.0 \mu \mathrm{mol} / \mathrm{L}$ AA was $2.92 \square$. So the detection of AA with DPV showed good selectivity, reproducibility, easy to use and is suitable for determination of enzymaticallygenerated AA over this concentration and one measurement can be finished within $10 \mathrm{~s}$.

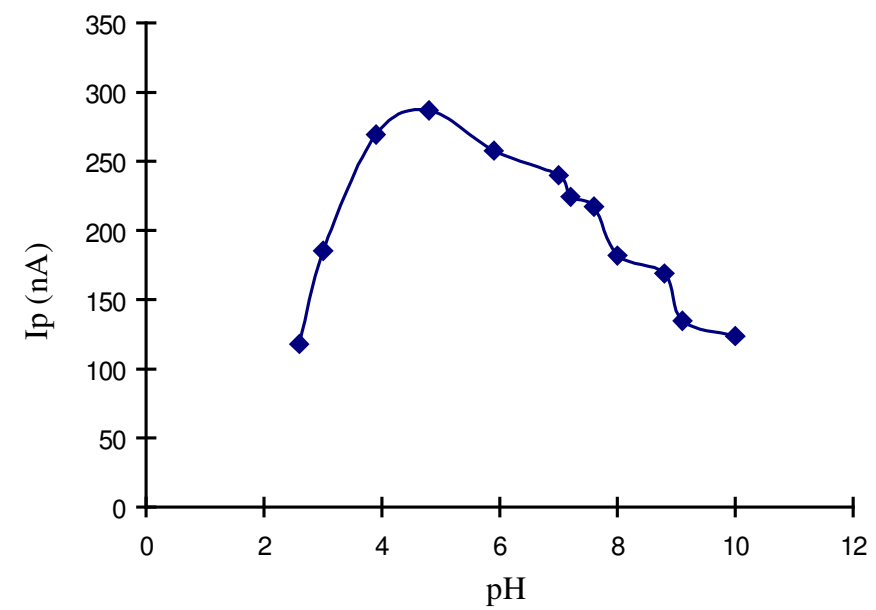

Figure 1. The influence of $\mathrm{pH}$ on the oxidative peak current of $10.0 \mu \mathrm{mol} / \mathrm{L} \mathrm{AA}$ in different Tris- $\mathrm{HCl}$ buffer. 
The AA solution is not stable in the air or under light, so the stability of AA solution was examined and the results are shown in Figure 2. Under the detection conditions, as for 20.0 $\mu \mathrm{mol} / \mathrm{L}$ AA solution, the electrochemical response remained constant within $10 \mathrm{~min}$, when the standing time was more than $10 \mathrm{~min}$, the oxidative peak current of AA decreased greatly, which was due to the oxidation of AA by oxygen in air. So highly purified nitrogen was used to remove the dissolved oxygen and the determination of AA should be finished within 10 min each time.

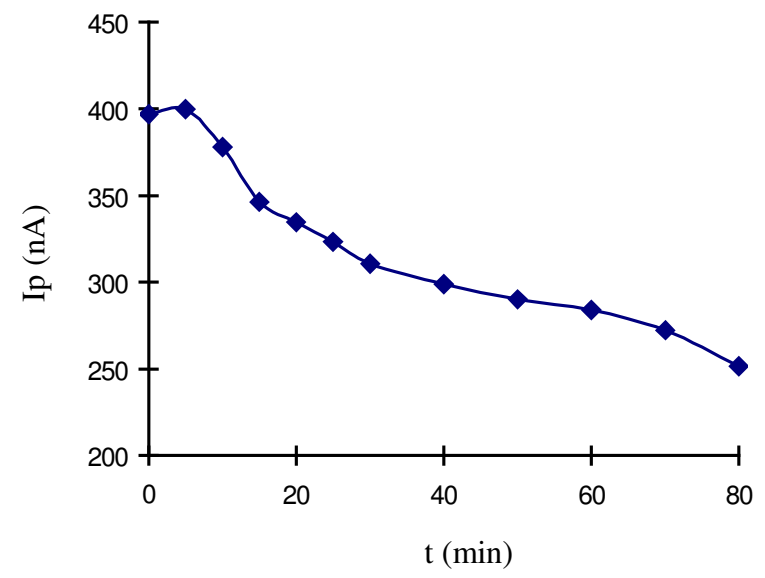

Figure 2. The stability of $20.0 \mu \mathrm{mol} / \mathrm{L} \mathrm{AA}$ solution in $0.05 \mathrm{~mol} / \mathrm{L} \mathrm{pH} 4.9$ Tris- $\mathrm{HCl}$ buffer.

Electrochemical studies of ascorbic acid 2-phosphate (AAP)

The cyclic voltammogram of ascorbic acid 2-phosphate (AAP) was also recorded and compared with that of AA. The results are shown in Figure 3. It can be seen that AAP has an irrevisible oxidative peak at $+860 \mathrm{mV}$ (curve 1) and AA has an oxidative peak at $+380 \mathrm{mV}$ (curve 2). Therefore the product, AA could be easily detected without the interference from the substrate, AAP.

\section{Differential pulse voltammogram of enzymatic reaction system}

In order to improve the sensitivity of the detection, differential pulse voltammetric method was used and the typical differential pulse voltammograms of enzymatic reaction system are shown in Figure 4. Curve 1 is the voltammogram of the substrate, AAP in Tris-HCl buffer solution, which has an oxidative peak at $+860 \mathrm{mV}$. After the addition of $10.0 \mathrm{U} / \mathrm{L}$ ALP, the enzymatic hydrolysis product AA, has a well-defined oxidative peak at $+380 \mathrm{mV}$ and the oxidative peak current of AAP decreased greatly, which indicated that the concentration of AAP in solution was decreased correspondingly due to the enzymatic catalytic reaction and the product AA was appeared in the reaction solution. So when the sweep peak potential range was fixed from 0 to $650 \mathrm{mV}$, the oxidative peak of the substrate AAP did not disturb the detection of the product AA. When the concentration of ALP was as low as the $0.4 \mathrm{U} / \mathrm{L}$, the oxidative peak current of AA can be found, which can be used for the detection of ALP concentration. 


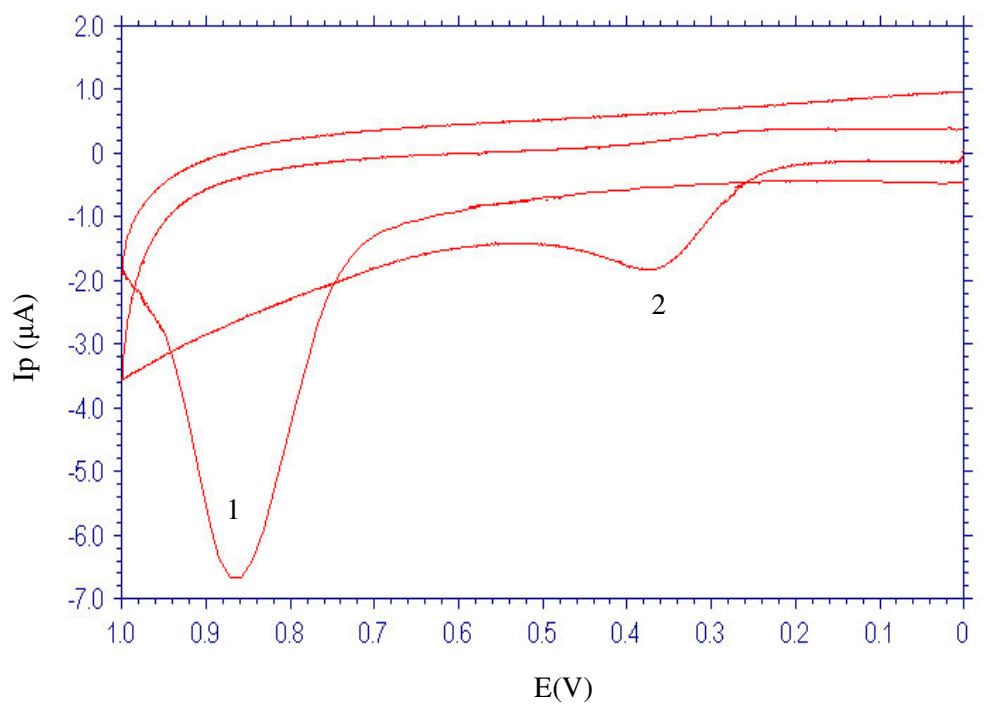

Figure 3. The cyclic voltammograms of AAP (1) and AA (2) in $\mathrm{pH} 4.9$ Tris- $\mathrm{HCl}$ buffer.

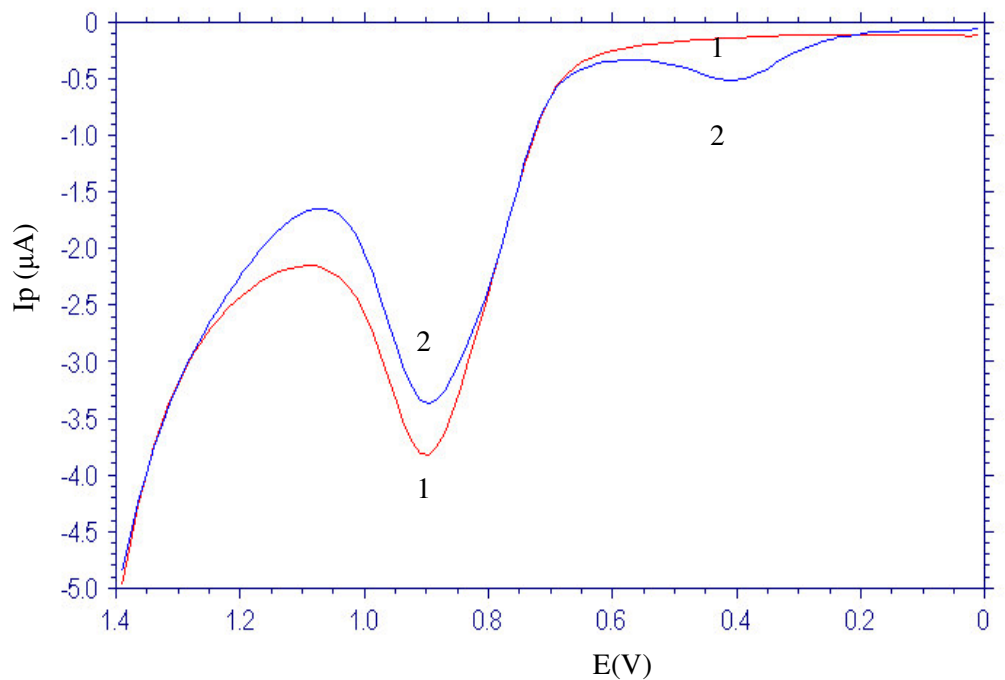

Figure 4. Differential pulse voltammograms of the ALP-AAP enzymatic reaction system. Reaction condition: $1.2 .0 \times 10^{-4} \mathrm{~mol} / \mathrm{L}$ AAP $+0.05 \mathrm{~mol} / \mathrm{L} \mathrm{pH} 8.8$ Tris-HCl; $2.1+10.0$ U/L ALP; detection condition: $\mathrm{pH} 4.9$ Tris-HCl.

Optimal conditions of enzymatic reaction and voltammetric detection

The enzymatic activity of ALP was greatly influenced by the reaction medium such as the $\mathrm{pH}$ and concentration of buffer, the reaction time and temperature. Different kinds of buffer, such 
as diethanolamine (DEA), Tris- $\mathrm{HCl}$, etc. were tested. Although these buffers are similar in structure and can promote the transphosphorylation of the substrate hydrolysis reaction. The results showed that $0.05 \mathrm{~mol} / \mathrm{L}$ Tris- $\mathrm{HCl}$ buffer was the optimal choice, which was in accordance with the reference [12]. Figure 5 shows the dependence of the oxidative peak current on the $\mathrm{pH}$ value of Tris- $\mathrm{HCl}$ buffer solution. The peak current reached maximum and remained stable at $\mathrm{pH} 8.8$, so $\mathrm{pH} 8.8$ Tris- $\mathrm{HCl}$ was chosen as the enzymatic reaction $\mathrm{pH}$ in the proposed method.

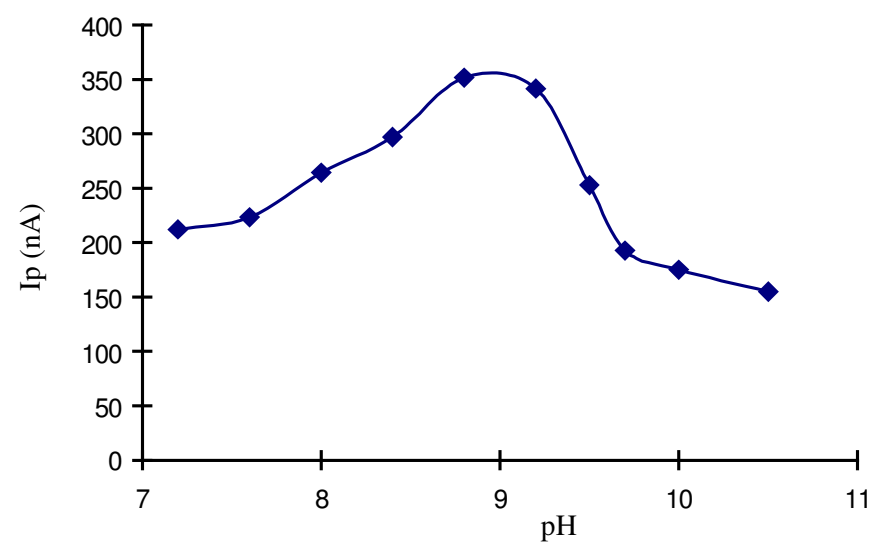

Figure 5. Influence of $\mathrm{pH}$ on ALP enzymatic reaction. Reaction condition: $2.0 \times 10^{-5} \mathrm{~mol} / \mathrm{L}$ AAP + $0.05 \mathrm{~mol} / \mathrm{L} \mathrm{pH} 8.8$ Tris-HCl + 10.0 U/L ALP; scan rate: $70 \mathrm{mV} / \mathrm{s}$.

The influence of the reaction temperature on the enzymatic activity was investigated from 10 ${ }^{\circ} \mathrm{C}$ to $50{ }^{\circ} \mathrm{C}$ and the results were shown in Figure 6. It can be seen that the peak current increased with the increase of the temperature and reached maximum at $37{ }^{\circ} \mathrm{C}$. When the temperature was more than $40^{\circ} \mathrm{C}$, the peak current decreased, which indicated that the ALP was lost activity at higher temperature. So $37{ }^{\circ} \mathrm{C}$ was chosen as the enzymatic reaction temperature and it was in agreement with the nature of ALP in human body.

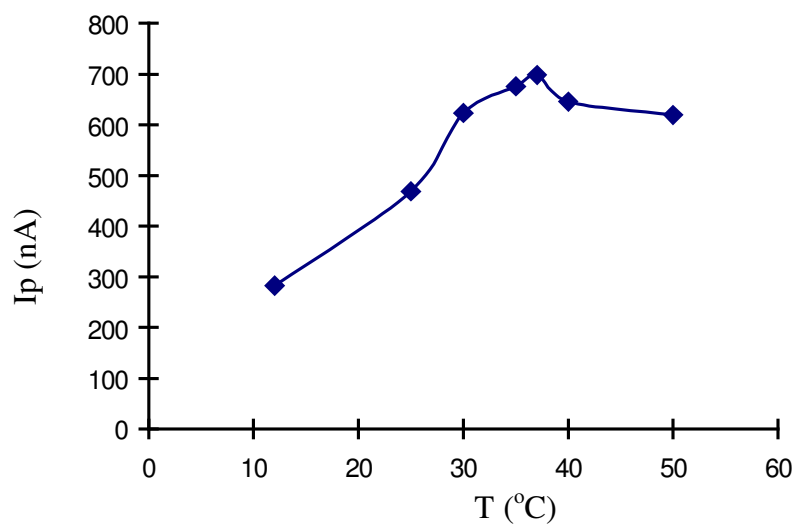

Figure 6. The influence of temperature on ALP reaction. Condition: $10.0 \mathrm{U} / \mathrm{L}$ ALP $+2.0 \times 10^{-5}$ $\mathrm{mol} / \mathrm{L} \mathrm{AAP}+\mathrm{pH} 8.8 \mathrm{Tris}-\mathrm{HCl}$ and reacted at different temperature for $30 \mathrm{~min}$.

Bull. Chem. Soc. Ethiop. 2005, 19(2) 
The influence of reaction time on ALP enzymatic reaction was also investigated at $37{ }^{\circ} \mathrm{C}$ and the results are shown in Figure 7. When the reaction time was more than 40 min, the reaction reached equilibrium. When the time was more than $45 \mathrm{~min}$, the blank response from the AAP non-enzymatic hydrolysis was increased greatly and can not be eligible, so the reaction time of 40 min was selected as the reaction time for the enzymatic reaction.

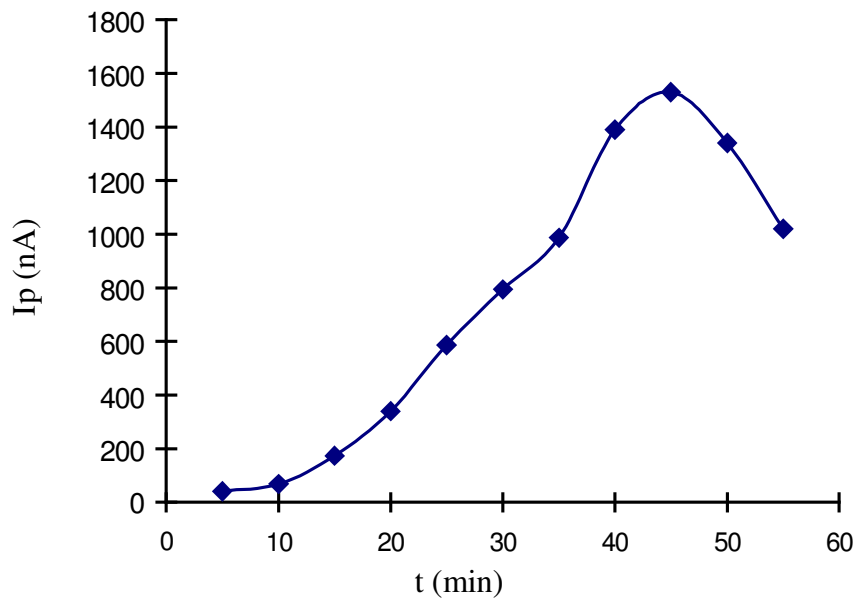

Figure 7. The influence of reaction time on ALP reaction. Condition: $10.0 \mathrm{U} / \mathrm{L}$ ALP $+2.0 \times 10^{-5}$ $\mathrm{mol} / \mathrm{L} \mathrm{AAP}+\mathrm{pH} 8.8$ Tris-HCl.

The stability of the substrate solution of AAP was tested. AAP solution was stable at room temperature for at least $3 \mathrm{~h}$ without changes in electrochemical response. But when it was mixed with $\mathrm{pH} 8.8$ Tris- $\mathrm{HCl}$ buffer solution, the hydrolysis reaction of AAP was increased greatly. In order to minimize the non-enzymatic hydrolysis reaction, the AAP substrate solution was prepared just before use.

The enzymatic reaction should be stopped after the selected reaction time. Generally speaking, different acid solutions such as $\mathrm{HCl}, \mathrm{H}_{2} \mathrm{SO}_{4}$ and $\mathrm{H}_{3} \mathrm{PO}_{4}$ were chosen to stop the reaction of ALP because ALP had the best activity at alkaline medium. In this paper $\mathrm{H}_{3} \mathrm{PO}_{4}$ was selected to stop the enzymatic reaction and $27.0 \mu \mathrm{L}$ of $4.0 \mathrm{~mol} / \mathrm{L} \mathrm{H}_{3} \mathrm{PO}_{4}$ was used to adjust the reaction $\mathrm{pH}$ of Tris- $\mathrm{HCl}$ buffer solution $(\mathrm{pH} \mathrm{8.8)}$ to the suitable detection $\mathrm{pH}(\mathrm{pH} 4.9)$ for the enzymatic product, AA.

Kinetic values for ALP catalytical reaction

Classical Michaelis-Menten kinetic experiments were carried out to measure the maximum velocity $V_{\max }$ and the apparent kinetic constant $K_{m}$ of this enzymatic reaction. The $V_{\max }$ and $K_{m}$ values were determined from the plots of the voltammetric response rate $(\mathrm{nA} / \mathrm{min})$ against the concentration of substrate $[\mathrm{S}]$ with the concentrations of the substrate varied from 0.4 to 1.0 $\mathrm{mmol} / \mathrm{L}$ and the reaction time within $30 \mathrm{~min}$.

From the following equation a Lineweaver-Burk plot of the experiment was performed.

$$
1 / \mathrm{V}=1 / \mathrm{V}_{\max }+\left(\mathrm{K}_{\mathrm{m}} / \mathrm{V}_{\max }\right) \cdot 1 /[\mathrm{S}]
$$

Bull. Chem. Soc. Ethiop. 2005, 19(2) 
Form the slope and intercept of the line the $\mathrm{V}_{\max }$ and $\mathrm{K}_{\mathrm{m}}$ were calculated as $0.33 \mathrm{~mol} / \mathrm{min}$ and $2.77 \mathrm{mmol} / \mathrm{L}$, respectively. Therefore, the substrate concentration of AAP was selected as 15.0 $\mathrm{mmol} / \mathrm{L}$, which was almost the value of $5 \times \mathrm{K}_{\mathrm{m}}$. At these excess amounts of substrate concentration, the enzymatic reaction was pseudo-zero and the reaction rate only depended on the enzyme concentration and not on the substrate solution.

\section{Electrochemical detection of ALP and labelled-ALP}

Under the selected optimal conditions the enzymatic reaction was carried out at $37{ }^{\circ} \mathrm{C}$ for 40 min with different quantities of standard ALP and the activity was measured by differential pulse voltammetry. As expected, the oxidative peak current of AA increased with the increase of the concentration of ALP and a linear range for ALP was found in the range of $0.4 \sim 2000.0 \mathrm{U} / \mathrm{L}$ with the detection limit $(3 \times \mathrm{N} / \mathrm{s})$ as $0.3 \mathrm{U} / \mathrm{L}$. The RSD of eleven parallel detections of $1.2 \mathrm{U} / \mathrm{L}$ ALP was $3.30 \%$ and the analytical parameters are listed in Table 1.

Table 1. The analytical parameters for ALP assay.

\begin{tabular}{|l|l|c|c|}
\hline Linear range (U/L) & Linear regression equation & $\mathrm{n}$ & $\gamma$ \\
\hline $0.4 \sim 12.0$ & $\mathrm{Ip}(\mathrm{nA})=9.18+44.94 \mathrm{C}(\mathrm{U} / \mathrm{L})$ & 8 & 0.999 \\
$12.0 \sim 100.0$ & $\mathrm{Ip}(\mathrm{nA})=281.04+89.19 \mathrm{C}(\mathrm{U} / \mathrm{L})$ & 6 & 0.997 \\
$200.0 \sim 2000.0$ & $\mathrm{Ip}(\mathrm{nA})=10153+13.52 \mathrm{C}(\mathrm{U} / \mathrm{L})$ & 5 & 0.995 \\
\hline
\end{tabular}

The goat anti-rabbit IgG labelled ALP (IgG-ALP) was also detected under the optimum conditions. As for the free labelled-ALP (IgG-ALP) the highest dilution ratios was 1:200000 with the dilution range as 1:1000 1:200000. The effect of the solid-phase carrier on the determination was also discussed. The IgG-ALP was adsorbed on the solid-phase carrier (polystyrene ELISA plate) for $2 \mathrm{~h}$ at $37{ }^{\circ} \mathrm{C}$ and then washed three times with phosphate buffer, the substrate solutions were then added and reacted at the optimum conditions, the results showed that the adsorbed labelled-ALP can be detected with the highest dilution ratios as $1: 20000$ with the range as 1:1000 1:20000.

\section{Effect of coexisting substances}

The influences of coexisting substances such as metal ions, amino acids, glucose and protein, etc. on the determination of 75.0 U/L ALP were tested and the results are listed at Table 2. It can be seen that low concentration of those commonly observed substances in the serum samples did not interfere with the determination.

Table 2. Effect of coexisting substances on the determination of 75.0 U/L ALP.

\begin{tabular}{|l|c|c|c|c|c|}
\hline $\begin{array}{l}\text { Coexisting } \\
\text { substance }\end{array}$ & $\begin{array}{c}\text { Concentration } \\
(\mathrm{mg} / \mathrm{L})\end{array}$ & $\begin{array}{c}\text { Relative } \\
\text { error }(\%)\end{array}$ & $\begin{array}{c}\text { Coexisting } \\
\text { substance }\end{array}$ & $\begin{array}{c}\text { Concentration } \\
(\mu \mathrm{mol} / \mathrm{L})\end{array}$ & $\begin{array}{c}\text { Relative } \\
\text { error }(\%)\end{array}$ \\
\hline L-Glutamic acid & 5.0 & 3.21 & $\mathrm{Mn}^{2+}$ & 2.0 & -4.48 \\
\hline L-Arginine & 5.0 & 3.74 & $\mathrm{Ca}^{2+}$ & 2.0 & 2.76 \\
\hline L-Tryptophan & 5.0 & -2.06 & $\mathrm{Co}^{2+}$ & 2.0 & -3.90 \\
\hline L-Leucine & 5.0 & 4.94 & $\mathrm{Cu}^{2+}$ & 2.0 & -5.30 \\
\hline L-Glutamine & 5.0 & 2.88 & $\mathrm{~Pb}^{2+}$ & 2.0 & 4.34 \\
\hline Citric acid & 5.0 & 2.62 & $\mathrm{Fe}^{3+}$ & 2.0 & 5.84 \\
\hline Glucose & 50.0 & 2.77 & $\mathrm{Urea}$ & 5.0 & 2.39 \\
\hline HSA $^{*}$ & 10.0 & -4.59 & $\mathrm{KCl}$ & 5.0 & 1.56 \\
\hline
\end{tabular}

*Human serum albumin. 
Determination of ALP activity in human serum sample

Human serum samples for ALP determination were obtained from the Hospital of Qingdao University of Science and Technology. Samples were diluted and analyzed by the proposed electrochemical method and the traditional $p$-nitrophenyl phosphate spectrophotometric method, respectively. The results are shown in Table 3 and there are in good agreement with each other. So this new electrochemical method is practical and reliable.

Table 3. Analytical results of ALP activity in human serum samples.

\begin{tabular}{|l|c|c|c|c|}
\hline Sample & This method (U/L) & RSD \% & $\begin{array}{c}\text { Spectrophotometri } \\
\text { c method (U/L) }\end{array}$ & RSD \% \\
\hline 1 & 68.2 & 3.05 & 70.4 & 2.37 \\
\hline 2 & 83.8 & 1.53 & 83.0 & 2.72 \\
\hline 3 & 80.4 & 1.72 & 78.2 & 1.34 \\
\hline
\end{tabular}

*average of three measurements

\section{CONCLUSION}

This paper has demonstrated the feasibility for the determination of ALP activity by voltammetric method with ascorbic acid 2-phosphate (AAP) as a new electrochemical substrate. The results show that AAP can be used as the suitable substrate for the routine ALP assay with satisfactory results. Compared with other commonly used electrochemical substrates, it is commercially available, inexpensive and has the low detection peak potential. The apparent is simple and easy to handle compared with flow injection analysis and HPLC. So this paper provides a potential for ALP electrochemical assay for the analysis of biological fluid with disposable working electrode or developing a biosensor for on line measurement.

\section{ACKNOWLEDGEMENTS}

The work was financially supported by the Natural Science Foundation of Qingdao City (04-2JZ-114), the National Natural Science Foundation of China (20405008, 20375020) and the China Postdoctoral Science Foundation (No.2003033492).

\section{REFERENCES}

1. Azmierczak, J.C.K.; Lott, J.A. Alkaline Phosphatase in: Methods in Clinical Chemistry, Pesce, A.J.; Kaplan, L.A. (Eds.), Mosby: St.Louis; 1987.

2. Bretaudiere, J.P.; Spillman, T. in: Methods of Enzymatic Analysis, Vol. IV, Bergmeyer, H.U. (Ed.), Verlag Chemie: Weinheim; 1986.

3. Tijssen, P. (Ed.), Practice and Theory of Enzyme Immunoassay, Elsevier: Amsterdam; 1985.

4. Shalev, A.; Greenberg, A.H.; Mcalpine, P.J. J. Immunol. Methods 1980, 30, 125.

5. Kokado, A.; Tsuji, A.; Maeda, M. Anal. Chim. Acta 1997, 337, 335.

6. Lasalle, A.L.; Limoges, B., Degrand, C. J. Electroanal. Chem. 1994, 379, 281.

7. Ciana, L.D.; Bernacca, G.; Bordin, F.; Fenu, S.; Garetto, F.; J. Electroanal. Chem. 1995, 382, 129.

8. Doyle, M.J.; Halsall, H.B.; Heineman, W.R. Anal.Chem. 1984, 56, 2355.

Bull. Chem. Soc. Ethiop. 2005, 19(2) 
9. Zhang, J.K.; Cass, A.E.G. Anal. Chim. Acta 2000, 408, 241.

10. Wijayawardhana, C.A.; Wittstock, G.; Halsall, H.B.; Heineman, W.R. Electroanalysis 2000, 12,640 .

11. Gehring, A.G.; Brewster, J.D.; Irwin, P.L.; Tu, S.I.; Van Houten, L.J. J. Electroanal. Chem. 1999, 469, 27.

12. Kreuzer, M.P.; O’Sullivan, C.K.; Guilbault, G.G. Anal. Chim. Acta 1999, 393, 95.

13. Jackson, S.D.; Halsall, H.B.; Pesce, A.J.; Heineman, W.R. Fresenius J. Anal. Chem.1993, $346,859$.

14. Togari, A.; Sakai, J.; Matsumoto, S. J. Chromatogr. 1987, 417, 41.

15. Kim, H.J.; Kwak, J.H. J. Electroanal. Chem. 2005, 577, 243.

16. Moore, E.J.; Pravda, M.; Kreuzer, M.P.; Guilbault, G.G. Anal. Lett. 2003, 36, 303.

17. Kokado, A.; Arakawa, H.; Maeda, M.; Anal. Chim. Acta 2000, 407, 119. 